\title{
Tourist Affiliate Program while Using Online Booking System with Possibility of Entering B2B Code
}

Slivar Iva*

\begin{abstract}
Affiliate marketing programs are one of the most powerful tools for online marketing since the merchant presenting a product or a service decides on the commisioning model and the commision is granted only if the desired results have been reached. Affiliate marketing is based offline as much as tourism itself and it relies on the commision that tourist companies pay to their partners (affiliates) who bring new guests. This paper will present the basics of how online affiliate programs work, benefits they bring and steps for their further implementation. It will explain in detail how to establish an affiliate program for dynamic web pages which use online booking system platforms that offer a possibility of entering a B2B code. Special attention will be paid to SEO (Search Engine Optimisation). It will also present results of a research on Croatian hotels web pages and the implementation of the online booking system and affiliate programs. Having in mind the insufficient deployment of online potentials, the aim of the paper is to stress the need for setting up an effective method of monitoring changes and updates in the online world as well as implementing new promotional possibilities, all aimed at increasing sales. The goal of the paper is to explore advantages and disadvantages of the affiliate program as a new sales channel and promote the possibility to implement it in one of the biggest Croatian hotel companies, Maistra d.d. Rovinj.

Along with methods of data acquiring and different techniques of creative thinking, the following scientific-research methods were also used: statistic, historic, descriptive, comparison, interview, analysis and synthesis, induction and deduction.
\end{abstract}

Key words: affiliate marketing, internet marketing, online marketing, hotels, Croatia

\section{Introduction}

Affiliate marketing programs are one of the most powerful tools for online marketing since the person presenting a product or a service decides on the commissioning model and the commission is granted only if the desired results have been reached.

* Maistra d.d., Obala V. Nazora 6, HR - 52210 Rovinj 


\section{Theory / issues}

Affiliate marketing programs are based on effectiveness of promotion where the promotion is paid for only after a certain number of sales, visits or subscription has been reached. Therefore factors according to which the basic payment models are determined are: Pay Per Sale, Pay Per Click, Pay Per Lead (Prussakov, 2007:11). Affiliate marketing was invented in November 1994 when the owner of CDNow.com web pages expressed the wish to cooperate with Amazon.com in order to recommend certain books (Wallington, Redfearn 2007:7).

Affiliate marketing based offline has been in use much longer. Here is an example from tourism: a receptionist recommends a restaurant to the customer. The receptionist then receives a commission from the owner of the restaurant as he has brought him a new customer. Figure 1. below shows how this model works online.

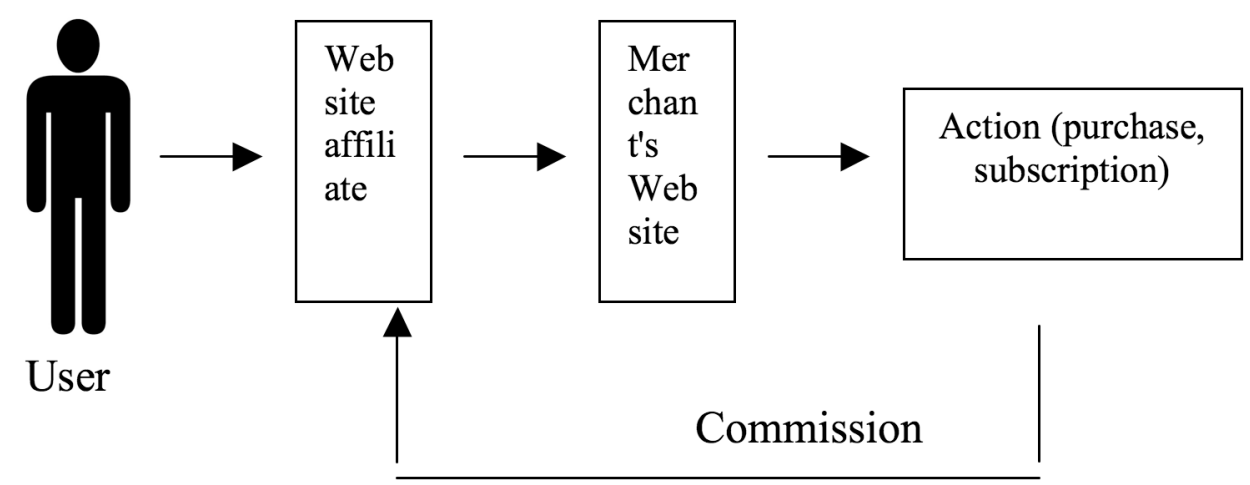

Figure 1. Online affiliate program

Source: elaborated by the author

The affiliate partner puts merchants' links on his web page and for each visitor who buys something off these links online; the affiliate receives a commission from the merchant.

What benefits do affiliate programs bring?

Benefits of affiliate programs for merchants are the following:

- promotion

- choice, possibility of "performance based" payment

- sale or some other transaction

- linking and SEO (search - engine - optimization) value

Promotion paid by effectiveness according to the selected model is the base of affiliate programs. What makes the promotion here different from classic advertising is that it is free of charge until the moment when the buyer takes a certain action. It is important to stress that this is not just any kind of promotion, but promotion on complementary web-sites that are not direct competitor or tour operators or tourist agencies. Incoming links present an additional value of affiliate marketing programs and are especially important for SEO (optimization of web pages for search engines like Google to give a web-page better rating when searching by certain key words). ${ }^{1}$

If the page A gives a link to the page B, search engines interpret it as the voice from the page A to the page $\mathrm{B}$, even if referred to in a negative context. Quality of links (form subject related sites ex. complementary sites) has greater importance than their quantity. 
Benefits of affiliate marketing programs for affiliate partners are: ${ }^{2}$

- flexibility

- money

- minimum initial capital

- no employees

- no offices

- the whole world is the market

\section{Methods / procedures}

It is possible to implement affiliate programs independently, or by using one of the numerous affiliate networks that offer required program support and connect affiliates with product and service suppliers. A list of European affiliate networks is available on the following web-pages: ${ }^{3}$

- http://www.amwso.com/eunetworks.php

- http://www.cumbrowski.com./affiliatednetworksinternational.asp

- http://www.e-consultancy.com/publication/affiliate-marketing-networks-buyersguide/(not very up-to-date, from 2006)

When starting a private affiliate program, it is necessary to use tracking software, hosting services or shopping cart for the affiliate (Prussakov, 2007:19).

The following activities are required, whether the affiliate program is established in-house or is outsourced:

1. preliminary research on the competition's affiliate programs

2. forming rules for affiliate partners

3. defining links

4. installing the affiliate program on web sites

For a hotelier who wishes to realize the sale of his products, model which is the most costeffective and also the most popular is PPS (Pay Per Sale), where a buyer can decide if commission will be charged in percentage or as a fixed amount on the basis of a commission scale. Some merchants reward the affiliates that bring the most visitors by granting them a higher commission, combining that way PPS and Pay Per Click models. Pay Per Lead models are applied in cases when a visitor must fill in a form on the service supplier's web-site. Pay per action models are used in cases when a visitor downloads, installs or uses a certain product or service.

Products and services can be promoted in various ways: through datefeeds (a complete product presentation on the affiliate pages), coupons with special discounts for visitors, textual links or banners, pictures and other. (Prussakov, 2007: 47-56). Textual links and banners are mostly used. Due to the so called banner blindness (users avoid looking at banners because they perceive them as advertisements), importance of anchor text (the part of text that forms a link) and better conversion, ${ }^{4}$ it is recommended to use textual links.

http://affiliate.blog.hr/2006/o9/index.html (03.07.2008)

http://forum.abestweb.com/showthread.php?=107367 (02.07.2008)

Conversion is mainly expressed in percentage and equals the ratio between realized actions (sale or subscription) and single visitors. It shows the percentage of users who go from visitors to buyers, or in tourism from lookers to bookers. The average conversion in tourism is about $2 \%$. The top ten online firms reach between $14.9 \%$ and $28.4 \%$ according to Nielsen/Net Ratings report from June 2008. 


\section{What to do when the web-page and the online booking system are on two different servers?}

Some online booking systems suppliers offer their own platform and hosting and also guarantee for the safety of the transaction. Hereafter a case of an affiliate program implementation in one of the leading tourist companies in Croatia, Maistra d.d., which is using one of such online booking systems will be presented.

Online booking system perceives each booking as the booking of a given company, except when entering a $\mathrm{B}_{2} \mathrm{~B}$ code. Statistics that it provides is available online in real time in the system's back-up and it shows all transactions performed. In this particular case it was not possible to provide $\mathrm{B}_{2} \mathrm{~B}$ partners with a user name and password for browsing the booking statistics since it would disclose all booking information. A very simple but expensive solution would be to exclude the company from the system.

Affiliate networks protect interests of their affiliates and try to find possibilities for monitoring the bookings even in cases when they do not make a profit on the basis of PPS. It is possible to track visitors and bookings by applying a tracking code on the "Thank you page" (the last page in the purchase process), which sends the booking ID, purchase amount and B2B code to the network. In the earl'ier given case the implementation of the network tracking code was not possible, which prevented the use of affiliate networks.

Consequently it was decided that a tracking solution and a private application for accessing the statistics should be created. It is necessary not only to track visitors and pages they came from, but also to understand whether these were affiliate partners' web-pages. Visitors can be tracked by cookies. ${ }^{5}$ Lifetime of a cookie can be adjusted to 30, 60, 90 days or more, the longer the better for the affiliate. It was determined that in tourism 30 days usually pass between the first search to the booking. All affiliate partners receive a $\mathrm{B}_{2} \mathrm{~B}$ code which is later used for online booking. The information about the site that the user came from is stored in cookies and if the site is on the list ${ }^{6}$ of $\mathrm{B}_{2} \mathrm{~B}$ affiliate partners, a $\mathrm{B}_{2} \mathrm{~B}$ code is also stored in the cookie.

The second option is to enter a $\mathrm{B}_{2} \mathrm{~B}$ code, for instance 123 , in the link: www.hotelierssite. $\mathrm{com} / \mathrm{id}=123$. This option is easier for implementation and tracking, but less advisable for SEO. Links that include ID parameters do not represent a direct link.

Information about $\mathrm{B}_{2} \mathrm{~B}$ code is entered into online booking in a way that it cannot be deleted (read only), whether it has been saved in cookies or in the integral part of the link.

Application for the statistics needs to have two parts: administrator's part for the affiliate manager and a part that can be accessed by the affiliate partners. Statistics is available online and can be accessed by entering password or user name.

Affiliate part includes:

- My account (information about the owner of the web-page from the contract)

- Internal statistics (visits, single visitors, sales traffic, commissions to be paid and monthly reports)

- Automatic calculation of total annual traffic, and if it exceeds the defined amount, the affiliate is transferred to the higher commission class.

5 Cookies are small textual files which certain sites save in visitors' computers in order to get various information about them and their preferences. According to the Commission Junk Research, only 1 $\%$ of users disable cookies as they believe they are protecting their privacy, although disabling cookies may affect the appearance of a certain web-page.

${ }_{6}$ The list represents all affiliate partners and their B2B codes saved in web-sites database. 
Administrator's part includes:

- Registering partners, their information and setting a $\mathrm{B}_{2} \mathrm{~B}$ code

- Overall affiliate statistics and statistics per individual affiliate (all items from the affiliate statistics and the calculation of the conversions booking/visiting and booking/single visitors).

- Possibility of marking the amount and time of payments.

- Possibility of monitoring the efficiency of particular banners or textual links

- Entering tables showing online booking system statistics with the date of the upload

Next step is finding the affiliate. In order to do that, it is possible to contact affiliate directories that are searching for suitable affiliates or perform the search manually. A less ethical way of finding affiliate partners is browsing the competition's links. Yahoo offers the most reliable information for finding links; all that one needs to do is simply enter: linkdomain: competition.com - site:competition.com. in the search box. A negative command excludes all links from the competition's web-sites. After potential affiliates have been identified, direct mailing ${ }^{7}$ is used inviting them to join the affiliate program. For affiliate program promotion it is possible to use Google Adwords like: "tourist affiliate program in Croatia".

After the affiliate program has been established, it needs to be further developed and extended through new acquisitions and by implementing new marketing possibilities as well as monitoring the efficiency of campaigns.

\section{Results}

During July of 2008 a research has been conducted on Croatian hotel companies' web-sites. The source of information was the list of categorized buildings in the category of hotels from the Ministry of Tourism of the Republic of Croatia, published on the web-site http:/www.mint. $\mathrm{hr} /$ default.aspx?id $=371$ and updated on $2^{\text {nd }}$ July 2008.

From the total number of 458 hotel companies, 466 web-sites were examined. The category "Overall without a web-site" also includes the category "Site under construction". Category "Site not in its own domain" refers to web-sites that have not their own web-page, but are using presentation web-sites that offer the possibility to contact the owner directly, or they are using a free hosting or domain service. The category "Errors on the site" refers to significant errors encountered during the attempt to open a web-page for three times or during the attempt to make a reservation when it was impossible to distinguish whether the hotel or the affiliate offers the online booking service. The results of the research are presented in table 1.

Out of five affiliate programs in Croatia, four belong to Starwood group- hotels Le Meridien Lav, Postrana near Split and the hotels in Zagreb-Westin, Sheraton and Four Points. All hotels use the same affiliate program on their web-sites: http.//www.starwoodhotels.com/ westin/affiliate/index.html. The fifth affiliate program is offered by the hotel Astoria in Zagreb: http://www.bestwestern.com/affiliate/index.asp. The described way of implementation of an affiliate program can be used with greater number of hotels that offer online booking, especially with larger companies since they use B2B code more often, e.g.: Valamar, National park Plitvička jezera, Ilirija, Solaris, HTP Korčula, Hotels Mlini, Hotels Sumartin and others.

7 On www.spancop.net you can find all requirements needed for such a mail not to be registered as a spam. In any case, mail personalisation helps. 
Table 1. Web-sites of hotel companies in Croatia: online booking and affiliate programs

\begin{tabular}{|c|c|c|c|c|c|c|c|}
\hline County & 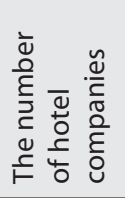 & 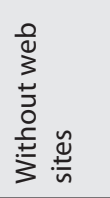 & 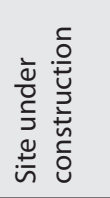 & 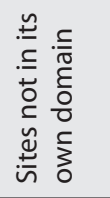 & 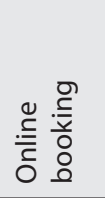 & 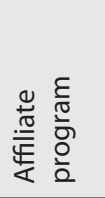 & 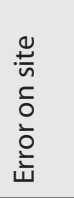 \\
\hline Istarska & 47 & 6 & 1 & 4 & 10 & 0 & 0 \\
\hline Primorsko - goranska & 72 & 2 & 0 & 1 & 6 & 0 & 2 \\
\hline Ličko - senjska & 9 & 2 & 1 & 0 & 1 & 0 & 1 \\
\hline Zadarska & 41 & 3 & 1 & 0 & 3 & 0 & 1 \\
\hline Šibensko - kninska & 22 & 3 & 0 & 0 & 4 & 0 & 0 \\
\hline Splitsko - dalmatinska & 107 & 7 & 2 & 0 & 16 & 1 & 0 \\
\hline Dubrovačko - neretvanska & 56 & 0 & 0 & 0 & 24 & 0 & 1 \\
\hline Zagrebačka & 36 & 2 & 1 & 0 & 10 & 4 & 0 \\
\hline Continental counties & 78 & 13 & 0 & 0 & 0 & 0 & 0 \\
\hline CROATIA TOTAL & $458^{*}$ & 38 & 6 & 5 & $73^{*}$ & 5 & 5 \\
\hline
\end{tabular}

\section{Conclusions}

There are numerous advantages that affiliate programs can offer to hoteliers since they can set their own commission as well as payment methods. The most widely spread commissioning model is PPS. This model does not require tracking of links as commission is granted only for finalized reservations. For hotel owners this means free promotion on complementary websites up until the very moment of purchase, and for affiliate partners it is a good way of making profit. Unlike classic advertising where hoteliers pay a set price in advance regardless of the result, results of this type of promotion are easily monitored and price is paid only after the final goal has been reached: the sale.

During July of 2008 a research on Croatian hotels' web sites was carried out that confirmed that only five hotels in Croatia have affiliate programs, four of which belong to the Starwood group. These results point out that most hoteliers in Croatia are not familiar with affiliate programs or do not perceive their advantages.

\section{Bibliography}

\section{Books}

Cox, B., Koelzer W.,(2005): Internet marketing: za hotele, restorane i turizam, M plus Zagreb. Kesić, T.,( 1997): Marketinška komunikacija, Mate, Zagreb,

Kotler, P. et al.,(1997): Marketing for Hospitality and Tourism", Prentice Hall, Upper Saddle River, NJ.

Prussakov, E.,(2007): A practical guide to affiliate marketing - Quick reference for affiliate managers and merchants, printed in the USA. 
Senečić J.,(1997): “Istraživanje turističkih tržišta”, Mikrorad i ekonomski fakultet Zagreb, Zagreb.

Wallington J., Redfearn D.,(2007).: "IAB Affiliate Marketing Handbook”, HBM Communications, London.

Journals

Brear, D., Barnes S.,(2008): Assessing the value of online affiliate marketing in the UK financial services industry, International Journal of Electronic Finance, Vol. 2, no.1, pp. 1-17.

Vlad I., (2003): "Industrial affiliate programs", Ad Astra, Vol. 2, No. 1. pp. 1-9.

Other

A best Web, http://forum.abestweb.com/showthread.php?t=107367_(2.7.2008.)

Adriatica.net, http://www.adriatica.net/jadran/opci_en.htm (8.7.2008.)

Affiliate Blog, http://affiliate.blog.hr/2006/og/index.html(3.7.2008.)

Grok.com, http://www.grokdotcom.com/2008/o7/24/top-10-online-retailers-by-conversionrate-june-2008/Top 10 online retailers by conversion rate June 2008 (24.7.2008.)

Ministry of tourism of Croatia, http://www.mint.hr/default.aspx?id=371(8.7.2008.) 